\title{
PENGARUH TERAPI BEKAM TERHADAP PERUBAHAN TEKANAN DARAH PADA PENDERITA HIPERTENSI DI DUSUN TAMBAK REJO DESA GAYAMAN MOJOKERTO
}

\author{
Yufi Aris Lestari ${ }^{1 *}$, Aris Hartono ${ }^{1}$, Ucik Susanti ${ }^{1}$ \\ ${ }^{1}$ STIKES Dian Husada Mojokerto \\ *Correspondence: \\ Yufi Aris Lestari \\ Email: yufiarislestari@gmail.com
}

\begin{abstract}
Background: Hypertension usually has no symptoms. That is why high blood pressure is called the silent killer. Hypertension that experienced by the public has been increase because most of them breaking treatment due to the high cost of treatment. One of the efforts made to resolve the issue with a non- pharmacological therapy but with cupping therapy.

Purpose: This study aimed to determine the effect of cupping therapy to changes in blood pressure on the patients with hypertension. Method: This reseach used design is Quasy experiment Pre-Test - Post Test Control Group. The population is patients with hypertension in the Tambak Rejo Village Gayaman District Mojokerto Regency were 28 people, sample in this study are 28 respondents and divided into two groups: experiment and control groups, with total sampling technique. The data obtained through observation sheet blood pressure were analyzed descriptively to determine differences in mean changes of blood pressure.

Results: The result show that there are differences between the mean of blood pressure on Pretest and Post Test. The experiment group average value of SBP change is $-28.57 \mathrm{mmHg}$, DBP $-10.71 \mathrm{mmHg}$ and MAP $-16.66 \mathrm{mmHg}$. In the otherside control group SBP 8.57 $\mathrm{mmHg}$, DBP $3.57 \mathrm{mmHg}$ and MAP $5.23 \mathrm{mmHg}$.

Conclusion: The reseach show that there is significant effect of cupping therapy for the patient with hypertension. And cupping therapy can be use as alternative therapy for patient with hypertension.
\end{abstract}

Key words: Cupping Therapy, Hypertension

\section{PENDAHULUAN}

Gaya hidup yang semakin komplek tanpa di sadari telah menimbulkan berbagai macam penyakit, salah satunya hipertensi. Hipertensi biasanya tidak mempunyai gejala. Kenyataannya, banyak orang yang mempunyai tekanan darah tinggi selama beberapa tahun tapi tidak mengetahuinya. Itulah sebabnya mengapa tekanan darah tinggi disebut pembunuh diam-diam atau silent killer (Ramadhan, 2010). Pengobatan hipertensi dapat dilakukan secara farmakologis dan non farmakologis, tetapi faktanya masih banyak masyarakat yang putus pengobatan. Di Dusun Tambak Rejo, Desa Gayaman Mojokerto terdapat penderita hipertensi yang putus pengobatan akibat mahalnya biaya yang harus dikeluarkan setiap kali berobat ke tenaga kesehatan. Namun, selain pengobatan farmakologis, ada pula pengobatan non farmakologis yang bisa dilakukan yaitu terapi bekam.

Kasus hipertensi sangat sering dijumpai diberbagai belahan dunia, prevalensi hipertensi dunia mencapai 
29,2\% pada laki-laki dan 24,8 \% pada perempuan (World Health Statistic, 2012). Sedangkan prevalensi hipertensi di Indonesia pada laki-laki sebanyak 32,5\% dan pada wanita sebanyak 29,3\% (World Health Statistic, 2012). Disamping itu penggunaan terapi bekam di Indonesia sudah banyak dikenal oleh masyarakat yang ditandai dengan mulai bermunculannya rumah atau klinik kesehatan yang menyediakan jasa terapi bekam (Nilawati, Krisnatuti, Mahendra, \& Djing, 2008). Dari hasil studi pendahuluan yang kami lakukan di Dusun Tambak Rejo, Desa Gayaman Mojokerto pada tanggal 13 Oktober 2014 dengan cara tanya jawab dengan beberapa warga yang menderita hipertensi sebanyak 9 orang, dimana 5 orang diduga putus pengobatan karena mahalnya biaya pengobatan, 3 orang diduga mengkonsumsi makanan yang dipercaya dapat menurunkan tekanan darah dan 1 orang tidak melakukan pengobatan diduga takut terhadap efek samping obat. Biaya yang harus dikeluarkan berkisar Rp. 30.000,00 sampai Rp. 50.000,00 setiap kali berobat ke tenaga kesehatan. Selain itu pengobatan farmakologis juga memiliki efek samping yang merugikan penderita.

Gangguan emosi, obesitas, konsumsi alkohol yang berlebihan, dan rangsangan kopi yang berlebihan, tembakau dan obat-obatan yang merangsang dapat berperan sebagai pemicu terjadinya hipertensi, tetapi penyakit ini sangat dipengaruhi oleh faktor keturunan. Tingginya tekanan darah yang lama tentu saja akan merusak pembuluh darah di seluruh tubuh, yang paling jelas pada mata, jantung, ginjal dan otak. Maka konsekuensi yang biasa terjadi pada hipertensi yang lama tidak terkontrol adalah gangguan penglihatan, oklusi coroner, gagal ginjal, dan stroke. Melihat kompleksnya permasalahan hipertensi dan adanya hambatan pengobatan hipertensi cara farmakologis akibat daya beli masyarakaat yang semakin menurun dan mempunyai harga yang cukup mahal, sehingga antisipasi dari permasalahan tersebut perlu di berikan terobosan baru pada masyarakat, bahwasanya pengobatan non farmakologis (terapi bekam) dapat menjadi pilihan alternatif yang bagus, baik segi ekonomi maupun manfaatnya. Seperti yang di jelaskan Ahmad Razak Sharaf (2012) menjelaskan bahwa bekam, melalui zat nitrtit oksida (NO), berperan meningkatkan suplai nutrisi dan darah yang di butuhkan oleh sel-sel dan lapisan - lapisan pembuluh darah arteri maupun vena, sehingga menjadikannya lebih kuat dan elastis serta mengurangi tekanan darah, zat nitrtit oksida (NO) juga berperan dalam vasodilatasion (proses perluasan pembuluh darah) sehingga menyebabkan turunnya tekanan darah.

Mengingat terapi farmakologi dan tingginya angka kejadian efek samping pada obat serta harga yang relatif mahal menjadikan pengobatan non farmakologis menjadi pilihan yang tepat. Salah satunya terapi bekam yang di percaya bisa menurunkan tekanan darah. Dengan demikian, masyarakat bisa meminimalisir pengunaan obat obatan hipertensi secara farmakologis yang biayanya cukup mahal. Berdasarkan latar belakang dan uraian tersebut di atas, peneliti tertarik untuk meneliti pengaruh terapi bekam terhadap perubahan tekanan darah pada penderita hipertensi.

\section{METODE DAN BAHAN}

Desain penelitian ini adalah Quasy Experiment dengan bentuk Pre-Post Test 
Control Group Design ialah rancang penelitian ini bertujuan untuk mengungkapkan hubungan sebab akibat dengan cara peneliti membagi dua kelompok yaitu kelompok eksperimen dan kelompok kontrol. Dalam rancang penelitian ini, kelompok eksperimen mendapatkan perlakuan sedangkan kelompok kontrol tidak.

Populasi dalam penelitian ini adalah penderita hipertensi di Dusun Tambak Rejo Desa Gayaman Mojokerto yang berjumlah 32 penderita sebagai populasi target. Setelah disesuaikan dengan kriteria penelitian, didapatkan populasi terjangkau berjumlah 28 penderita. Sampel berjumlah 28 penderita dari keseluruhan penderita di Dusun Tambak Rejo Desa Gayaman Mojokerto, 14 penderita sebagai kelompok eksperimen dan 14 penderita lagi sebagai kelompok kontrol. Pengambilan sampel dalam penelitian ini menggunakan teknik total sampling.

Pengambilan data pre test dilakukan dengan melakukan observasi satu persatu penderita hipertensi baik kelompok kontrol maupun kelompok eksperimen.

Pengambilan data post test dilakukan dengan observasi satu persatu pada kelompok eksperimen setelah terapi bekam diberikan. Pengambilan data post test pada kelompok kontrol juga dilakukan observasi satu persatu. Data yang dikumpulkan pada pre test dan post test ini berupa data tekanan darah, didapatkan dengan cara peneliti melakukan observasi langsung tekanan darah pada penderita hipertensi di Dusun Tambak Rejo, Desa Gayaman Mojokerto yang dijadikan sampel baik kelompok kontrol maupun kelompok eksperimen. Tekanan darah sebelum dilakukan terapi bekam dimasukkan pada kolom tekanan darah (pre test) lalu dilakukan penghitungan MAP (Mean Arterial Pressure) untuk mengetahui nilai rata-rata tekanan arteri atau nilai rata-rata tekanan darah saat pre test, dan tekanan darah sesudah dilakukan terapi bekam dimasukkan pada kolom akhir (post test). Perlakuan dalam penelitian ini yaitu dengan memberikan terapi bekam. Sedangkan pada kelompok kontrol tidak diberikan perlakuan (tidak diberikan terapi bekam). Terapi bekam tidak diberikan oleh peneliti sendiri dikarenakan peneliti tidak memiliki sertifikat bekam. Maka terapi bekam tersebut diberikan oleh terapis yang sudah berpengalaman dalam proses pembekaman dan memiliki sertifikat resmi. Terapi bekam pada kelompok eksperimen diberikan 2 kali dalam sebulan dengan waktu selama 20 menit. Dan alat bekam yang digunakan dengan merk Kangzhu Cupping Kit dan alat tesebut disterilisasikan setiap selesai pemakaian untuk mencegah penularan.

\section{HASIL PENELITIAN}

\section{JENIS KELAMIN}

Karakteristik

responden berdasarkan jenis kelamin hampir seluruhnya perempuan, yaitu sebanyak 10 responden $(71,4 \%)$ pada kelompok eksperimen dan sebanyak 9 responden $(64,3 \%)$ pada kelompok kontrol. Data tersebut dapat dilihat di tabel 1.

Tabel 1. Distribusi Responden Berdasarkan Jenis Kelamin di Dusun Tambak Rejo Desa Gayaman Mojokerto.

\begin{tabular}{|c|c|c|c|c|}
\hline \multicolumn{2}{|c|}{} & \multicolumn{2}{|c|}{ Jenis Kelamin } & Total \\
\cline { 3 - 5 } \multicolumn{2}{|c|}{} & $\begin{array}{c}\text { Laki- } \\
\text { laki }\end{array}$ & Perempuan & \\
\hline \multirow{3}{*}{ Kelompok } & \multirow{3}{*}{ Eksperimen } & 4 & 10 & 14 \\
\cline { 3 - 5 } & \multirow{3}{*}{ Kontrol } & $28,6 \%$ & $71,4 \%$ & $100 \%$ \\
\cline { 3 - 5 } & & 5 & 9 & 14 \\
\cline { 3 - 5 } & & $35,7 \%$ & $64,3 \%$ & $100 \%$ \\
\hline \multirow{2}{*}{ Total } & 9 & 19 & 28 \\
\cline { 3 - 5 } & $32,2 \%$ & $67,8 \%$ & $100 \%$ \\
\hline
\end{tabular}




\section{USIA}

Karakteristik responden berdasarkan usia pada kelompok eksperimen sebagian besar berusia 40 tahun dan kelompok kontrol sebagian besar berusia 37 tahun. Data tersebut dapat dilihat di tabel 2.

Tabel 2. Distribusi Responden Berdasarkan Usia di Dusun Tambak Rejo Desa Gayaman Mojokerto.

\begin{tabular}{|c|c|c|c|c|c|}
\hline \multicolumn{2}{|c|}{} & \multicolumn{4}{|c|}{ Usia } \\
\cline { 3 - 6 } \multicolumn{2}{|c|}{} & Mean & Maks. & Min. & $\begin{array}{c}\text { Std. } \\
\text { Deviasi }\end{array}$ \\
\hline \multirow{2}{*}{ Kelompok } & Eksperimen & 40 & 49 & 31 & 5,9 \\
\cline { 2 - 6 } & Kontrol & 37 & 44 & 31 & 3,7 \\
\hline
\end{tabular}

\section{LAMA MENDERITA HIPERTENSI}

Karakteristik responden berdasarkan lama menderita hipertensi sebagian besar 1-5 tahun lamanya menderita hipertensi, yaitu berjumlah 13 responden $(92,9 \%)$ pada kelompok eksperimen dan berjumlah 12 responden $(85,7 \%)$ pada kelompok kontrol. Data dapat dilihat di tabel 3.

Tabel 3. Distribusi Responden Berdasarkan Lama Menderita Hipertensi di Dusun Tambak Rejo Desa Gayaman Mojokerto.

\begin{tabular}{|c|c|c|c|c|c|}
\hline \multicolumn{2}{|c|}{} & \multicolumn{3}{|c|}{ Lama Menderita Hipertensi } & Total \\
\cline { 3 - 6 } \multicolumn{2}{|c|}{} & $\begin{array}{c}<1 \\
\text { Tahun }\end{array}$ & $\begin{array}{c}1-5 \\
\text { Tahun }\end{array}$ & $\begin{array}{c}>5 \\
\text { Tahun }\end{array}$ & \\
\hline \multirow{3}{*}{ Kelompok } & \multirow{3}{*}{ Eksperimen } & 1 & 13 & 0 & 14 \\
\cline { 3 - 6 } & $7,1 \%$ & $92,9 \%$ & $0 \%$ & $100 \%$ \\
\cline { 2 - 6 } & \multirow{3}{*}{ Kontrol } & 2 & 12 & 0 & 14 \\
\cline { 3 - 6 } & $14,3 \%$ & $85,7 \%$ & $0 \%$ & $100 \%$ \\
\hline & \multirow{2}{|c|}{ Total } & 3 & 25 & 0 & 28 \\
\cline { 3 - 6 } & $10,7 \%$ & $89,3 \%$ & $0 \%$ & $100 \%$ \\
\hline
\end{tabular}

\section{TEKANAN DARAH SEBELUM TERAPI BEKAM}

Pada kelompok eksperimen nilai rerata tekanan darah sistol (TDS) sebesar $161,42 \mathrm{mmHg}$, rerata tekanan darah diastol
(TDD) adalah 100,00 $\mathrm{mmHg}$ dan Mean Arteria Pressure (MAP) nya adalah 120,45 mmHg. Sedangkan pada kelompok kontrol sebelum diberikan terapi bekam nilai rerata tekanan darah sistol (TDS) sebesar 155,71 $\mathrm{mmHg}$, rerata tekanan darah diastol (TDD) adalah 100,71 mmHg dan Mean Arteria Pressure (MAP) nya yaitu $119,01 \mathrm{mmHg}$. Data dapat dilihat di tabel 4.

Tabel 4. Hasil Pengukuran Tekanan Darah Sebelum Terapi Bekam Pada Kelompok Eksperimen Dan Kelompok Kontrol Di Dusun Tambak Rejo Desa Gayaman Mojokerto.

\begin{tabular}{|c|c|c|c|c|c|c|}
\hline & \multicolumn{7}{|c|}{ Tekanan Darah Pre-Test } \\
\hline & \multicolumn{2}{|c|}{ Kelompok Eksperimen } & \multicolumn{3}{c|}{ Kelompok Kontol } \\
\cline { 2 - 7 } & TDS & TDD & MAP & TDS & TDD & MAP \\
\hline Mean & 161,42 & 100,00 & 120,45 & 155,71 & 100,71 & 119,01 \\
\hline $\begin{array}{c}\text { Nilai } \\
\text { Maks. }\end{array}$ & 190,00 & 120,00 & 136,60 & 190,00 & 120,00 & 140,00 \\
\hline $\begin{array}{c}\text { Nilai } \\
\text { Min. }\end{array}$ & 140,00 & 90,00 & 110,00 & 140,00 & 90,00 & 110,00 \\
\hline SD & 12,92 & 9,60 & 9,12 & 16,50 & 9,16 & 9,46 \\
\hline N & \multicolumn{7}{|c|}{14} & & \multicolumn{4}{|c|}{14} \\
\hline
\end{tabular}

\section{TEKANAN DARAH SETELAH TERAPI BEKAM}

Pada kelompok eksperimen setelah diberikan terapi bekam, nilai rerata tekanan darah sistol (TDS) sebesar 132,85 mmHg, rerata tekanan darah diastol (TDD) adalah 89,28 mmHg dan Mean Arteria Pressure (MAP) nya adalah 103,78 mmHg. Sedangkan pada kelompok kontrol setelah diberikan terapi bekam nilai rerata tekanan darah sistol (TDS) sebesar 164,28 mmHg, rerata tekanan darah diastol (TDD) adalah 104,28 mmHg dan Mean Arteria Pressure (MAP) nya yaitu $124,25 \mathrm{mmHg}$. Data dapat dilihat di tabel 5. 
Tabel 5. Hasil Pengukuran Tekanan Darah Setelah Terapi Bekam Pada Kelompok Eksperimen Dan Kelompok Kontrol Di Dusun Tambak Rejo Desa Gayaman Mojokerto.

\begin{tabular}{|c|c|c|c|c|c|c|}
\hline & \multicolumn{6}{|c|}{ Tekanan Darah Post Test } \\
\hline & \multicolumn{2}{|c|}{ Kelompok Eksperimen } & \multicolumn{3}{c|}{ Kelompok Kontol } \\
\cline { 2 - 7 } & TDS & TDD & MAP & TDS & TDD & MAP \\
\hline Mean & 132,85 & 89,28 & 103,78 & 164,28 & 104,28 & 124,25 \\
\hline $\begin{array}{c}\text { Nilai } \\
\text { Maks. }\end{array}$ & 160,00 & 100,00 & 120,00 & 180,00 & 120,00 & 136,60 \\
\hline $\begin{array}{c}\text { Nilai } \\
\text { Min. }\end{array}$ & 120,00 & 80,00 & 93,30 & 150,00 & 100,00 & 116,60 \\
\hline SD & 13,25 & 7,30 & 8,26 & 11,57 & 6,46 & 5,90 \\
\hline N & & 14 & & \multicolumn{4}{|c|}{14} \\
\hline
\end{tabular}

\section{PENGARUH TERAPI BEKAM TERHADAP PERUBAHAN PERUBAHAN TEKANAN DARAH PADA PENDERITA HIPERTENSI}

Pada kelompok eksperimen PrePost Test, nilai rerata perubahan tekanan darah sistol (TDS) sebesar -28,57 mmHg, rerata perubahan tekanan darah diastol (TDD) adalah $-10,71 \mathrm{mmHg}$ dan rerata perubahan Mean Arteria Pressure (MAP) nya adalah $-16,66 \mathrm{mmHg}$. Sedangkan pada kelompok kontrol Pre-Post Test, nilai rerata perubahan tekanan darah sistol (TDS) sebesar 8,57 $\mathrm{mmHg}$, rerata perubahan tekanan darah diastol (TDD) adalah 3,57 $\mathrm{mmHg}$ dan perubahan Mean Arteria Pressure (MAP) nya yaitu 5,23 $\mathrm{mmHg}$. Data dapat dilihat di tabel 6.
Tabel 6. Pengaruh Terapi Bekam Terhadap Perubahan Tekanan Darah Pada Penderita Hipertensi Antara Kelompok Yang Diberikan Terapi Bekam Dengan Kelompok Yang Tidak Diberikan Terapi Bekam Di Dusun Tambak Rejo Desa Gayaman Mojokerto.

\begin{tabular}{|c|c|c|c|c|c|c|}
\hline & \multicolumn{6}{|c|}{ Perubahan Pre-Post Test } \\
\hline & \multicolumn{2}{|c|}{ Kelompok Eksperimen } & \multicolumn{2}{|c|}{ Kelompok Kontol } \\
\cline { 2 - 7 } & TDS & TDD & MAP & TDS & TDD & MAP \\
\hline Mean & $-28,57$ & $-10,71$ & $-16,66$ & 8,57 & 3,57 & 5,23 \\
\hline $\begin{array}{c}\text { Nilai } \\
\text { Maks. }\end{array}$ & 0,00 & 10,00 & 3,40 & 40,00 & 20,00 & 20,00 \\
\hline $\begin{array}{c}\text { Nilai } \\
\text { Min. }\end{array}$ & $-60,00$ & $-30,00$ & $-40,00$ & $-30,00$ & $-20,00$ & $-23,40$ \\
\hline SD & 15,61 & 10,71 & 10,46 & 16,10 & 11,50 & 11,46 \\
\hline N & & 14 & & & 14 & \\
\hline
\end{tabular}

\section{PEMBAHASAN}

\section{Hasil Pengukuran Tekanan Darah Sebelum Terapi Bekam}

Berdasarkan hasil penelitian yang telah dilakukan menunjukkan bahwa sebelum diberikan terapi bekam, nilai rerata TDS, TDD dan MAP nya tinggi pada kelompok eksperimen maupun pada kelompok kontrol.

Tekanan darah itu sendiri merupakan tekanan dari aliran darah dalam pembulu darah nadi atau arteri (Kowalski, 2010). Kekuatan tekanan darah ke dinding pembulu darah yang menampung mengakibatkan tekanan ini berubah-ubah pada setiap siklus jantung. Apabila terjadi suatu keadaan dimana tekanan darah sistol diatas $140 \mathrm{mmHg}$ dan diastol diatas 90 $\mathrm{mmHg}$, maka disebut hipertensi (Smeltzer \& Bare, 2001).

Sedangkan hipertensi yang tidak ditangani akan menyebabkan berbagai komplikasi pada penderita tersebut diantaranya seperti stroke, jantung koroner dan gagal ginjal. Mengingat parahnya komplikasi yang akan terjadi, seharusnya penderita melakukan pengobatan untuk mengobati hipertensi tersebut. Dengan pengobatan tersebut diharapkan akan memberikan efek penurunan tekanan darah 
yang ditandai dengan stabilnya tekanan darah sistol maupun diastol.

\section{Hasil Pengukuran Tekanan Darah Setelah Terapi Bekam}

Berdasarkan hasil penelitian yang telah dilakukan menunjukkan bahwa setelah diberikan terapi bekam, nilai rerata TDS, TDD dan MAP nya menurun pada kelompok eksperimen. Sedangkan pada kelompok kontrol nilai rerata TDS, TDD dan MAP nya tetap tinggi.

Terjadi perbedaan rerata tekanan darah sebelum diberikan terapi bekam dan setelah diberikan terapi bekam pada kelompok eksperimen. Bekam itu sendiri merupakan suatu metode pembersihan darah dengan mengeluarkan sisa toksik dalam tubuh melalui permukaan kulit dengan cara menyedot (Ahmad Fatahillah, 2006).

Perbedaan tersebut dipengaruhi oleh adanya perlakuan pemberian terapi bekam pada kelompok eksperimen 2 kali selama sebulan dalam waktu 20 menit setiap sekali bekam. Sedangkan pada kelompok kontrol tidak diberikan perlakuan berupa terapi bekam. Sehingga pada kelompok eksperimen mengalami penurunan rerata tekanan darah sedangkan pada kelompok kontrol tidak.

\section{Analisis Pengaruh Terapi Bekam Terhadap Perubahan Tekanan Darah.}

Berdasarkat hasil penelitian menunjukkan bahwa dari hasil observasi perubahan nilai rerata tekanan darah Pre tes dan Post Test didapatkan perubahan tekanan darah baik pada kelompok eksperimen maupun kelompok kontrol. Namun perubahan tersebut berbeda, terjadi penurunan nilai rerata tekanan darah pada kelompok eksperimen dan terjadi peningkatan tekanan darah pada kelompok kontrol.

Hal tersebut terjadi karena adanya perlakuan yang berbeda pada kelompok tersebut. Pada kelompok eksperimen diberikan terapi bekam sedangkan pada kelompok kontrol tidak. Seperti yang di jelaskan Wadda' Amani Umar (2008), memberikan penjelasan berbeda tentang cara kerja bekam. Menurutnya, pembekaman biasanya dilakukan pada permukaan kulit (kutis), jaringan bawah kulit (sub kutis) jaringan ini akan "rusak". Akibat kerusakan ini akan dilepaskan beberapa zat seperti serotin, histamine, bradiknin, slow reaction substance daerah yang dibekam. Dilatasi kapiler juga dapat tenjadi di tempat yang jauh dari tempat pembekaman. Ini menyebabkan terjadi perbaikan mikrosirkulasi pembuluh darah. Akibatnya timbul efek relaksasi (pelemasan) otot-otot yang kaku serta akibat vasodilatasi umum akan menurunkan tekanan darah secara stabil.

Sehingga dapat disimpulkan bahwa adanya pengaruh pemberian terapi bekam terhadap penurunan tekanan darah pada penderita hipertensi.

\section{SIMPULAN}

Terdapat pengaruh terapi bekam terhadap penurunan tekanan darah dan terapi bekam ini dapat dijadikan alternative pengobatan bagi penderita hipertensi.

\section{SARAN}

Saran dalam penelitian ini adalah lebih dipromosikannya tentang terapi bekam sebagai terapi alternative bagi penderita hipertensi, perlu lebih banyak lagi dibangunnya balai pengobatan terapi bekam yang legal dan disediakannya terapi 
alternative berupa terapi bekam di berbagai fasilitas kesehatan.

\section{DAFTAR PUSTAKA}

1. Brunner \& Suddart. 2002. Buku Ajar Keperawatan Medical Bedah. Jakarta: EGC

2. Dalimartha, S., Purnama, B.T., Sutarina, N., Mahendra, B., \& Darmawan, R. 2008. Care Your Self, Hipertensi. Jakarta: Penebar Plus

3. Davey, Patrick. 2005. Medicine at a Glance. Jakarta: Erlangga

4. Depkes. 2014. Klasifikasi Hipertensi. www.depkes.go.id . (Diakses tanggal 02 Desember 2014)

5. Fatahillah, Ahmad. 2006. Keampuhan Bekam. www.books.google.co.id . (Diakses 10 Oktober 2014)

6. Gray, Huon H. 2005. Lecture Notes Kardiologi. Jakarta: Erlangga

7. Guyton \& Hall. 2007. Buku Ajar Fisiologi Edisi II. Jakarta: EGC

8. Kaplan, Norman M. 1991. Pencegahan Penyakit Jantung Koroner. Jakarta: EGC

9. Kowalsky, R.E. 2010. Terapi Hipertensi. Bandung: Qanita

10. Martiani, Lili \& Tantan. 2007. 100 Questions 7 Answers Hipertensi. Jakarta: PT. Elex Media Komputindo

11. Mary. 2001. Care Your Self, Hipertensi. Jakarta: Penebar Plus

12. Master Yunus. 2014. Bekam Pengobatan Menurut Sunnah Nabi. www.books.google.co.id . (Diakses 1 Desember 2014)

13. Muhammadun, AS. 2010. Hidup Bersama Hipertensi. Yogyakarta: iNBooks

14. Nilawati, S., Krisnatuti, D., Mahendra, \& Djing, O.G. 2008. Care Yourself, Kolesterol. Jakarta: Penebar Plus.

15. Pikir, B.S. 2003. Ilmu Penyakit Jantung. Surabaya: AirlanggaUniversity Press

16. Rasidi. 2005. Terapi Bekam . www.pelatihanbekam.org . (Diakses 15 November 2014)
17. Samuel, F. 2007. Smart Treatment For High Blood Pressure. Jakarta: PT. Prestasi Pustakaraya

18. Sharaf, A Razak. 2012. Penyakit Dan Terapi Bekamnya. Surakarta: Thibbia

19. Susalit, dkk. 2001. Pengobatan Hipertensi. Jakarta: Gramedia Pustaka Utama

20. Susiana Jansen, Darwin Karim, Misrawati. 2013. Efektifitas Terapi Bekam Terhadap Penurunan Tekanan Darah Pada Penderita Hipertensi Primer. Universitas Riau.

21. Sustrani, dkk. 2006. Hipertensi. Jakarta: Gramedia Pustaka Utama

22. Sutanto. 2010. Cekal Penyakit Modern Hipertensi, Stroke, Jantung, Kolkesterol Dan Diabetes. Yogyakarta: CV. Andi Offset.

23. Syaifuddin. 2006. Anatomi Dan Fisiologi Untuk Mahasiswa Keperawatan Edisi 3. Jakarta: EGC

24. Turana, Y. 2010. Bagaimana Mengukur Tekanan Darah Yang Benar. www.medikaholistik.com. (Diakses tanggal 27 Desenber 2014)

25. Umar, Wadda' A. 2008. Sembuh Dengan Satu Titik. Solo: Al-Qowam

26. Umar. 2008. Penelitian Tentang Bekam.

www.islamichealingcentre.com

(Diakses 29 November 2014)

27. Wahdah, N. 2011. Menaklukan Hipertensi Dan Diabetes: Mendeteksi, Mencegah dan mengobati dengan cara Medis dan Herbal. Yogyakarta: CV.Multi Solusindo.

28. World Health Statistic. 2012. Frace: World Health Organization

29. Yasin. 2005. Bekam Sunnah Nabi \& Mukjizat Medis. Solo: Al-Qowam

30. Zaki, Muhammad. 2012. Lima Terapi Sehat. Jakarta: Gramedia 